\title{
Learning history integrated local wisdom values "babad Banyumas" to build a student's national identity
}

\author{
Ngismatul Khoeriyah ${ }^{1, *}$, Warto ${ }^{2}$, and Sariyatun ${ }^{3}$ \\ ${ }^{1}$ Post Graduate in History Education, faculty of Teacher Training and Education, Universitas Sebelas \\ Maret, Surakarta, Indonesia \\ ${ }^{2}$ Professor of History Science, Universitas Sebelas Maret, Surakarta, Indonesia \\ ${ }^{3}$ Professor of History Education, Universitas Sebelas Maret, Surakarta, Indonesia
}

\begin{abstract}
This study aims to build a national identity and collective memory of students through learning history that is integrated with the values of local wisdom Babad Banyumas, which is considered ideal teaches values in learning history. The study employed a qualitative descriptive research method through literature review. The results show that in Babad Banyumas have values that match the character's learning, such as: 1) Social values, it is illustrated in the Babad Banyumas that is $\mathrm{Ki}$ Dipati Kaleng's attitude in entertaining his guest; 2) the value of morality, this is demonstrated by Raden Baribin's attitude of confronting a power conflict with his brother; 3) The value of religiosity include spiritual attitude shown by Dipawijaya the form of asceticism beg a boon to the Supreme Court and tradition Sang Hyang every Friday night visit to the palace followed by reciting Qur'an in Surau (mosques king).
\end{abstract}

Keywords: learning history; local wisdom, babad Banyumas, national identity.

\section{Introduction}

The phenomenon of low character education in school inevitably we have to think about it. Because the education of values that concern the formation of the character of learners has not been applied maximally. Considering how the current state of education in Indonesia is illustrated, cases that are inconsistent with ethics, morality, courtesy or behaviour that indicate low morality have become so prevalent in society. More worrying, the behaviour is not shown by few people who are educated. This proves that education is less successful in shaping the character is good. Under such conditions, it would be relevant to recount the old paradigm of education, namely education as a legacy of values.

In relation to that according to Thomas Lickona there are 10 signs of human behavior that indicate the direction of destruction of a nation that is: 1) increasing violence and vandalism among adolescents; 2) dishonest dishonesty; 3 ) increasing height of disrespect to

*Corresponding author: ngismatulkhoeriyah3@gmail.com 
parents, teachers and leaders; 4) the influence of peer group against acts of violence; 5) increased suspicion and hatred; 6) the use of deteriorating language; 7) decline of work ethic; 8) decreasing the sense of responsibility of individuals and citizens; 9) the heightened self-destructive behavior, and 10) the escape of moral guidance [1].

Considering how the current state of education in Indonesia is illustrated, cases that are inconsistent with ethics, morality, courtesy or behaviour that indicate low morality have become so prevalent in society. More worrying, the behaviour is not shown by few people who are educated. This proves that education is less successful in shaping the character is good. Under such conditions, it would be relevant to recount the old paradigm of education, namely education as a legacy of values. The legacy of cultural values of the past is not small that contains the values of character and moral education. This is honestly caused on January 10, 2010, kemendiknas organized a workshop so the emergence of the idea of the declaration on "Culture and National Character Education" as a national movement [2].

Ideally, the application of character education in educational institutions is integrated with subjects that have the content of local wisdom as part of the nation's character formation. Character education that must be developed in schools is the religious values and cultural values of the nation (local wisdom). The material content taught in character education is inseparable from the local wisdom that is held by the people. The local wisdom that exists in society is one of the material content that must be contained in character education. History is a subject that teaches about value education is expected to have a significant role in the strengthening of education in Indonesia.

The history lesson aims to create historical insights or historical perspectives. Historical insights further highlight the continuity of everything. Being is the result of the process of becoming, and being itself is in the process of becoming a point. Meanwhile, the sociocultural nature of our environment is a product of history, including the territory of RI, national state, national culture. National History multidimensional functions include prevention of determinism, expand intellectual horizons, to prevent the occurrence of synchronism, which ignores the determinism [3].

Babad Banyumas as an ancestral cultural heritage, in this research, is integrated with learning history to build national identity and collective memory of students. Babad Banyumas is considered ideal in teaching values in the model of teaching history because it contains many values of character that is learning about manners, tolerance, fairness, honest, responsible, integrity, discipline, courage, mercy (welas asih), the generosity shown by the figures in the babad as Raden Baribin, Raden Kaduhu, Adipati Warga Utama, Adipati Mrapat, Adipati Janah, dan Tumenggung Yudanegara, where overall indicators are exemplary by learners. Through the overall values, students are expected to learn and understand the noble culture that comes from the region and become the inspiration in reflecting himself, the surrounding environment and nation.

\section{Methodology}

The study employed a descriptive-qualitative research method derived from literature reviews by searching for written sources, whether in the form of books, archives, articles, and journals, or documents relevant to the subject matter studied.

\section{Result and Discussion}

The results of this study found that learning history based on Babad Banyumas can build national identity and collective memory of students. In the Javanese literary tradition, tembang books generally contain teachings about noble values or guidance. This is different 
from the gendhing-gendhing dolanan whose content is more entertainment. Babad Banyumas as an ancestral cultural heritage, in this research, is integrated with the learning of history to build the identity and collective memory of students either in the realm of cognitive, affective, psychomotor or connotation.

The results of the research findings in the field of SMK case studies as Banyumas (with a sample of three schools: SMK N 1, SMKN 2, SMKN 3 Banyumas) with the update of curriculum 2013 which emphasizes on values and character education. With the existence of KI (Core Competence), scientific approach and with models that can build students' activeness and criticality in learning as well as the existence of historical lesson material integrated with local wisdom of Babad Banyumas, so it makes it easier for students to understand the local culture and heritage. When compared with previous historical learning (not yet integrated with local wisdom), history learning is only limited to studying events within the national scope. It is reinforced by Nadlir, that this educational model, learning materials must have meaning and high relevance to their empowerment of life in real, based on the reality they face. The curriculum must be prepared is a curriculum that is appropriate to the environmental conditions, interests, and psychological condition of learners. It should also take into account the sociological and cultural constraints they face. Local wisdombased education is education that teaches learners to always stick with the concrete situation they face. Because faced with the problems and concrete situations encountered, learners will be more challenged to respond critically [4].

History-based learning design Babad Banyumas is based on the needs and problems of low identity and awareness of student character values. According to researchers, Babad Banyumas must be actualized in the contemporary context. The actualized Babad Banyumas is part of the planning process which includes a learning design process that produces products in the form of draft models or syntax, learning tools and learning modules. The product is then implemented in classroom teaching through a scientific approach with supporting modules and learning media. After going through the implementation phase then the learning model in the evaluation whether it has been in accordance with the goals and indicators. The resulting product is then a historical learning model based Babad Banyumas that contains aspects of cognitive, affective, and psychomotor.

One of the regeneration processes for the delivery of local wisdom as a reinforcement of the Banyumas identity is through literary works, such as Banyumas diverse Babad version. Knowledge of past community in Indonesia is very close to the oral tradition and writing tradition, from here also perhaps the intellectual roots of the Java community can be tracked. In a society that has not known the writing of oral tradition has been used as one way to pass down the collective memory or knowledge of the past gained from previous generations.

Wolf Kansteiner defines collective memory as representations of the past that are collectively adopted [5]. Collective memory is a general category that includes several main kinds of memories. First is the popular memory, defined by David Midelton and Derek Edwards as representations of the past held by the society's members, best manifested directly by public opinion surveys [6]. This memory significantly influences the psychological dynamics mentioned above and the behavioral reactions of the people holding it, and therefore, it is accorded great importance [7]. The second kind is the official memory, according to Jeffrey Olick: the representations of the past adopted by the institutions of the state. This memory is manifested, for instance, by publications of state ministries and the army, exhibitions in national museums, and textbooks approved for use in the educational system [8]. Third is the autobiographical memory, that of the people who directly experienced the events, manifested typically in memoirs and oral histories. This is a primary source for the past (in addition to documents) and is therefore usually 
accorded importance [9]. Fourth is the historical memory, the way the research community mostly academics as well as independent scholars views the event in its studies of the past [10]. Fifth and final is the cultural memory defined by Ian Assmann as the way the society views its past via newspaper articles, memorials, monuments, films, and buildings [11].

Local wisdom education also has a very important role in the development of national identity. As Vikers says, nation building involves more than the simple promotion of a language. It also aims at socializing youngsters in a particular national culture and historical narrative [12]. Babad as one source of history until now still not used by many historians. Perhaps because theoretically and methodologically the babad has many shortcomings, especially when it is associated with temporal, factual or spatial issues. In addition, because it is a literary work, the Babad using literary language elusive hole common people. Babad Tanah Jawi, for example, is still not fully understood about the origin, intent, material and its components. De Graaf mentions that Babad Tanah Jawi is a strange writing. There are allegations that the babad was written by several people aimed at strengthening the legitimacy of the ruling king [13]. Last but not least the fill factor that is sometimes unacceptable to common sense, the more distanced historian's attention to this literary work. Apart from all these weaknesses, babad actually also contains some historical facts. In this case, Taufik Abdullah states that through literary works we can understand the procession of past events and recapture the time structure of reality. Taufik Abdullah further states that literary work is a collective experience of the author and reflects the mood of time when the work was created [14].

Babad Banyumas is a living tradition of the text that gave rise to new and varied texts. The creativity of the authors and copyists shows high productivity [15]. Babad Banyumas versions are in fact very necessary in enriching the repertoire of local wisdom Banyumas. Babad Banyumas is considered ideal in teaching values in history learning. Because in the Babad Banyumas contains many good values that is learning about manners, tolerance, fairness, honest, responsible, integrity, discipline, courage, compassion, generosity shown by the figures in the Babad such as Raden Baribin, Raden Kaduhu, Adipati Warga Utama, Adipati Mrapat, Adipati Janah, and Tumenggung Yudanegara, all of which indicate that the indicators are worthy of being followed by the students. In the babad Banyumas it basically contains a lot of life values grouped into core values such as the value of morality, social value, and the value of religiosity.

\subsection{Value of Morality}

Research on moral education has drawn on ethical philosophy, developmental, psychology, and constructivist pedagogy to show that individuals can develop the capacity for moral reflection and judgment, which becomes increasingly inclusive, principled, and independent of the dictates of established authorities [16]. In this tradition, critical judgment consists of an active process in which participants a) recognize multiple moral dilemmas and contested issues that cannot be resolved relying simply on personal preferences, formed habits, and social traditions, and b) engage with these dilemmas and controversies through reasoned dialogue, seeking to recognize different view points and coordinate them in judgments and choices that are comprehensive, fair, and responsive to rights and needs of different parties in conflict. Moral judgment becomes critical in so far as it takes reflective distance from one's egocentric and socio-centric prespective, and is self-directed, yet sensitive to and inclusive of others [17].

Babad Banyumas teaches moral guidance as a part of character education that can be classified as personal ethics because it is a more self-directed ethical guide. As the teachings in Javanese culture emphasize patience. This is demonstrated by the journeys of Raden Baribin in his struggle for power. Where he had to fight for his life expelled from his 
own home due to a dispute with his ambitious brother in power. This can be known from the contents of the babad

// warnanen ingkang lumaris / wus medal sangking nagara / lesu forgot sarirane / tillar spirits opponent nendra / tiyang saurut marga / tanana ngaturi suguh / ajrih undhange san nata //

Translation:

This is all due to the threat of the prabu who has strictly prohibited to accept or entertain them.

Until finally, Raden Baribin stumbled due to tired and hungry he suffered. Then came in the pagagan area, where he found the fruit the cucumber.

However, the babad banyumas also alludes to the importance of the development of reason, thought, rationality or intellect. About the ethos of learning (science), that science can be possessed with the practice that begins with a strong will.

// Raden Kedhuhu kang wewasi / wus diwasa pamit mring kang Rama / tuwin mring ibu sorine / arsa anganyut tuwuh / kesah sangking praja nireki / sumeja anglelana / ngetan kang dinunung / prapteng tanah lurung tengah / pan ing wirasaba ingkang den enggoni / jumeneng Adipati //

The translation:

Raden Kedhuhu son Raden Baribin as an adult, he permits to rama's mother to wander looking for science to flee to the eastern country and come in wirasaba, he became there later with the name of Adipati Wirautama.

\subsection{Social Value}

Babad Banyumas teaches some moral guidance as part of a character education that can be classified as a social value because it is an ethical guideline more expressed to others and to its social environment. In it is taught to act decently in the meeting. Because in Babad Banyumas illustrated that the good person is usually sociable to get along with various circles. This is explained in the stanza:

// ri sampunya sinuguh / ing wau kyai Dipati / parentahi dadya mira / kinen akaryaha sami / pasareyan ing pandhapa / bade gene Kyai Tolih //

The translation:

After ending the conversation then Ki Dipati Kaleng entertained her guests with food and joy, then prepared the bed for Kyai Tolih special in pendhapa.

\subsection{Religiosity Value}

Babad Banyumas teaches some moral guidance as part of character education that can be classified as the value of religiosity. That religion is a precious grip of life. Javanese religious views which often use the terms of Islam. It is depicted in a stanza that reads:

// amung antepana sira kaki / suwita ing katong / aya anak putu nira tembe / antuk kanugrahanning Hyang Widi / kawruhaning ngaji / witana sireku //

// sawusnya ntuk kawan dasa hari / gya luwar sang anom / pan kacathet ing driya wisike /

langkung sukur donga ing Hyang Widi / samono wus lami / genya suwiteng riku //

// saben malem jumuah ing wengi / sowan ing karaton / sareng lawan perdikan lebete / darus aneng suranatan masjid / duk sawiji wengi / kangjeng kang sinuwun // 
The translation:

Doing tapa pendem for forty days, then he got a wangsit at the will of Sang Hyang Widhi that Dipawijaya will not get the position he wants, name to continue to serve the sang katong. Then after forty days, he ended his khalwat. Since the incident, every Friday night Dipawijayapun visit to the palace then followed by reciting al-qur'an in Surau (king's mosque).

\section{Conclusion}

Learning history integrated local wisdom values "Babad Banyumas" as a treasure of local wisdom of Banyumas community can certainly build the identity and collective memory of students. Because in it contains many values that can be the handle of the learner's life as a form of character education and Banyumas community as the heir and guardian of culture, which values are summarized in moral values, social values, and the value of religiosity shown by the figures in the babad such as Raden Baribin, Raden Kaduhu, Duke Residents Main, Duke Mrapat, Duke Janah, and Tumenggung Yudanegara, which overall core values are exemplary by Banyumas community and the Indonesian people, in general, to build a national identity through such wisdom. By taking these values, students are expected to learn and understand the noble culture that comes from the region and become an inspiration in reflecting himself and his environment in order to have an identity. Thus many ways that can be done through the exploration of local wisdom values for awakening identity and collective memory of learners. One of them through Babad Banyumas.

\section{References}

1. T. Lickona, Ed for Char, (Bandung, Penerbit Nusa Media, 2014).

2. Z. Darmiyati, Pendidikan Karakater, (Yokyakarta, UNY Press, 2010)

3. S. Kartodirdjo, Pendekatan Ilmu Sosial, (Jakarta, Gramedia Pustaka Utama, 1993)

4. Nadlir. Urgensi Pembelajaran. Jurnal Pendidikan Agama Islam, 02, 306 (2014)

5. W. Kansteiner, Finding Meaning in Memory, History and Theory, 41, 179- 197 (2002)

6. D. Midelton, D. Edwards, Collective Remember. (London, Sage Publications, 1997).

7. E. Halperin, D. Bar-Tal, R. Nets-Zehngut, E. Drori, Emotions in Conflict, Peace and Conflict, 14, 233-258 (2008); I. Shelter, Historical Memory as a Foundation for Peace, Journal of Peace Research, 47, 649-650, (2010)

8. Jeffrey Olick, What does it Mean to Normalize the Past, Social Science History, 22, 547-571 (1998); W. Zheng, National Humiliation, History Education, and the Politics of Historical Memory, International Studies Quarterly, 52, 783-806 (2008)

9. K. Jennings, N. Zhang, Generations, Political Status, and Collective Memories, The Journal of Politics, 67, 1164-1189 (2005); H. Schumann, H. Akiyama, B. Knauper, Collective Memory of Germans and Japanese, Memory, 6, 427-454 (1998)

10. J. Winter, E. Sivan, Setting the Framework, in War\&Remembrance in the Twentieth Century, J. Winter, E. Sivan, (Cambridge: Cambridge University Press, 1999), 6-39.

11. J. Assmann, Collective Memory\&Cultural, New German Critique, 65, 125-133 (1995)

12. Vickers, E. Introduction: History, Politics and IEA, International Journal of Educational Research 37, 537-44 (2002)

13. H.J. De Graaf, De Regering van Panembahan Senapati, (Jakarta, Grafitti Pers, 1985)

14. B, Purwanto, Gagalnya Historiografi Indonesiasentris, (Yogyakarta, Ombak, 2006)

15. S. Priyadi, "Babad Banyumas, (Purwokerto: FKIP UMP, 2013)

16. L. Kohlberg, The psychology of moral development, (San Francisco, harper\&row 1984)

17. A. Bermudez, Four tools for critical, Revista de estudios sociales, 52, 102-118, (2014) 